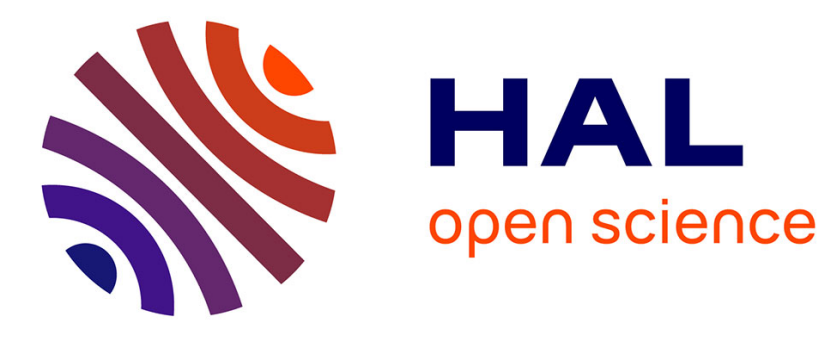

\title{
Concrete pathologies in sewer structures: microstructural analysis
}

Mehena Oualit, Raoul Jauberthie, M. Tahar Abadlia

\section{To cite this version:}

Mehena Oualit, Raoul Jauberthie, M. Tahar Abadlia. Concrete pathologies in sewer structures: microstructural analysis. Journal of Building Pathology and Rehabilitation, 2019, 4 (1), pp.12. 10.1007/s41024-019-0051-y . hal-02473271

\section{HAL Id: hal-02473271}

\section{https://hal-univ-rennes1.archives-ouvertes.fr/hal-02473271}

\author{
Submitted on 14 Feb 2020
}

HAL is a multi-disciplinary open access archive for the deposit and dissemination of scientific research documents, whether they are published or not. The documents may come from teaching and research institutions in France or abroad, or from public or private research centers.
L'archive ouverte pluridisciplinaire HAL, est destinée au dépôt et à la diffusion de documents scientifiques de niveau recherche, publiés ou non, émanant des établissements d'enseignement et de recherche français ou étrangers, des laboratoires publics ou privés. 


\section{Concrete pathologies in sewer structures: Microstructural analysis}

Mehena. Oualit $^{\mathrm{a} *}$, Raoul. Jauberthie ${ }^{\mathrm{b}}, \mathrm{M}^{\mathrm{ed}}$ Tahar. Abadlia $^{\mathrm{a}}$

${ }^{a}$ Unit of Research: Materials, Processes and Environment (UR-MPE), Frantz Fanon city, 35000 Boumerdès, Algeria.

${ }^{b}$ Laboratory of Civil and Mechanical Engineering (LGCGM) - INSA of Rennes, France.

Corresponding author: oualitmehena@yahoo.fr , mobile: +213777152300 


\begin{abstract}
Corrosion of concrete sanitary sewers has become a major problem around the world. Concrete durability in sewerage systems is mainly related to the presence of effluents containing sulfurrich compounds that lead to an acid attack and expansion reactions. This paper presents a microstructural analysis of concretes (two case studies) taken from corroded sewer pipes. The objective of this investigation is to highlight and identify the pathologies of cementitious materials in sanitation networks. A scanning electron microscope equipped with energy dispersive X- ray analysis (SEM- EDS) was performed on fragments of concrete samples taken at different areas. In addition to these microstructural analysis, bulk density and wateraccessible porosity tests are performed, the results obtained were compared with those of a reference concrete (new pipe). The results of the analysis showed a deterioration of the pipes in both faces (internal and external) with the presence of products prejudicial for their durability.
\end{abstract}

Keywords: Concrete sewer; SEM-EDS analysis; pathologies; durability; degradation.

\title{
1. Introduction
}

The durability of concretes in sewerage networks is essentially linked to the presence of effluents rich in sulfur compounds, sources of an acid attack and cause chemical reactions that lead to the formation of expansive products $[1,2]$. The release of hydrogen sulfide can occur in septic tanks, sewage treatment plants and sewer systems. This release originates from the decomposition, in anaerobic environment (nonoxygenated environment), of the sulfur compounds contained in the effluents stirred or circulating in the structures.

Corrosion of concrete caused by hydrogen sulfide has been recognized as a serious problem in collection systems for the past century $[3,4,5]$. The problem of hydrogen sulfide induced concrete corrosion is known in collection systems in most of the world $[6,7,8]$. In some of the worst cases, the lifetime of sewer pipes and pumping stations 
has been reduced to less than ten years $[9,3]$. Besides the costs of restoration, the costs of preventive measures should also be considered when estimating the economic impact of hydrogen sulfide related problems [10].

When hydrogen sulfide is taken up by the concrete pipe surface it is oxidized to sulfuric acid $\mathrm{H}_{2} \mathrm{SO}_{4}$. The oxidation of hydrogen sulfide on the pipe surface is biological after the $\mathrm{pH}$ of the surface has dropped below approximately 8-9 [4, 5].

The acid reacts with the alkaline components of the concrete, mainly calcium hydroxide and calcium carbonate. The product of this reaction is mainly gypsum [11, 12], which has little structural strength for which reason the concrete pipe is weakened [13, 14]. Jarosite $\left(\mathrm{KFe}_{3}\left(\mathrm{SO}_{4}\right)_{2}(\mathrm{OH})_{6}\right)$ and ettringite $\left(\mathrm{Ca}_{4} \mathrm{Al}_{2}\left(\mathrm{SO}_{4}\right)(\mathrm{OH}) .2 \mathrm{H}_{2} \mathrm{O}\right)$ have also been identified as components in the corrosion products $[11,15,16]$. Figure 1 illustrates and summarizes the corrosion process that occurs in sewers and concrete structures.

This paper presents a part of a vast preventive study on the aging of sewerage networks in the city of Rennes (France). It is dedicated solely to the detection of sewer concrete pathologies by microstructural analysis. The objective of this study is to highlight and identify the concrete pathologies of deteriorated sewer pipes. Two cases studied are presented in this research.

\section{Materials and methods}

\subsection{General data and sampling}

As maintenance work and sewer replacement work continues in the City, samples of pipe are recovered for analysis. For each sample taken back ground information is logged onto a data base:

- Catchment type - separate or combined sewerage.

- Catchment area, population and industrial waste discharges. 
- $\quad$ Physical pipe details - diameter and gradient.

- Date of construction.

- Local soil conditions.

Specimens with a diameter of $28 \mathrm{~mm}$ were cored in recovered pipe samples. Cores were taken in three directions; $\mathrm{R}$ - radial, $\mathrm{T}$ - transversal and $\mathrm{L}$ - longitudinal. The cores $\mathrm{L}$ and $\mathrm{T}$ taken from the pipe are used to assess alterations to the matrix of the concrete; those taken in the radial direction are used to study the alterations at to the external and internal faces of the pipe.

To study these alterations, the cores are examined by visual observation and scanning electron microscope (SEM) coupled with energy dispersal X ray spectroscopy (EDS). In addition to these microstructural analysis, bulk density and water-accessible porosity tests are performed. The results obtained were compared with those of a reference concrete (new pipe, not yet in use).

Two examples are described in this paper. The first case, 'Rue Jean Ogée' concerns a conduct of a unitary network. The pipe section examined shows a slight deterioration of the internal surface and a significant damage to the outer portion with important section loss (of material).

This section of the sewerage system was constructed in 1965 to serve an area of multistorey apartments. The pipe in question is $400 \mathrm{~mm}$ in diameter and $55 \mathrm{~mm}$ in thick; it forms the first pipe section in the pipe run with a gradient of $1.25 \%$. The pipe collects from a population of approximately $150-200$ people. The soil in the area from which the pipe was taken is clay resulting from altered biovérien schist.

The second case study 'Rue saint Helier' is a sample taken from a 1,680 $\times 800 \mathrm{~mm}$ ovoid-shaped piece of pipe from a unitary network. A very old pipe, set up since 1892 with a very important thickness estimated at $209 \mathrm{~mm}$. The pipe consists of large red 
block likely sandstone or shale joined together by porous concrete. Takeoffs and cracks can be observed between the blocks and the binder. The outer surface is sandy and rough. The sewer has a catchment of $0.61 \mathrm{~km}^{2}$ serving a population of 6000 inhabitants. The pipe is located in a residential area and shops. This reach of the sewer is $48 \mathrm{~m}$ long and has a gradient of $3.75 \%$. The soil in this area is a clayey subsoil, the clay emanating from altered biovérien schist.

\subsection{SEM-EDS analysis}

The SEM-EDS analysis are performed on the cylindrical samples (R) taken at midheight of the pipes. This zone is chosen because it is the most vulnerable $[17,18]$. These analysis were carried out on fragments of samples that were previously subjected to indirect tensile strength using the Brazilian test method. Fragments of samples were taken from specific areas namely: proximity of the outer face, close to the inside and the median zone.

These samples are glued on a conductive support covered with a palladium gold Au-Pd conductor before launching SEM observations.

\subsubsection{Apparatus and procedures}

A conventional JEOL JSM 6400 SEM is used, allowing the observation of dry and conductive samples and atomic analysis by an INCA OXFORD Link energy dispersion spectrometer.

The final preparation of non-conductive samples is carried out by:

- Drying of hydrated samples by Balzers CPD 010 critical point apparatus;

- Sputtering metallization with JEOL JFC 1100 (conductive gold-palladium layer);

- Carbon deposit per Emscope TB500 device (carbon conductive layer).

The observations are made either in secondary electrons or in backscattered electrons. 


\section{Results and discussion}

\subsection{SEM examination and EDS analysis: Case study 1}

\subsubsection{Outside area}

The SEM analysis of a fragment of the concrete taken near the outer face of the pipe is illustrated in Figure 2. It may be noted that the concrete in contact with the ground of this pipe is slightly porous (Figure 2(b)). In Figure 2(a), the development of ettringite needles in a pore can be distinguished. An ettringitic nature confirmed by the EDS analysis (Figure 3) carried out on the point of spectrum 1 of the Figure 2(a), in particular with the presence of aluminum (Al) and sulfur (S). Moreover, the EDS analysis of the point of spectrum 2 in Figure 2(b) also shows the presence of portlandite which can be converted into calcite with the presence of $\mathrm{CO}_{2}$, its composition is shown in Figure 4.

\subsubsection{Inner area}

The visualizations performed on a fragment taken from the inner face of the pipe, Figure 5, reveal a formation of sulphates which appears in the form of needles (on the right of Figure 5(a)) with the chemical composition of ettringite (see Figure 6). On the other hand, the left part which appears in the form of a hard crystal is a mixture between CSH of cement and portlandite.

Moreover, Figure 5(b) shows the altered state of this zone with highly degraded and sulphated cement. The microanalysis at the point of spectrum 1 of Figure 5(b) is shown in Figure 7. In the case of 'Rue Jean Ogée', the sewer is at the head of a network and oversized for its function; a $400 \mathrm{~mm}$ diameter sewer to service a population of approximately 200 population. The consequence of this situation is that during the night the flow in the sewer will be virtually non existent, and any sewage retained in the 
reach will become anaerobic, a condition that will favour the generation of hydrogen sulfide gas and consequently lead to sulphate attack of the sewer lining. Being at the head of the sewer, the natural ventilation will be limited.

\subsubsection{Median zone}

Like the extremities, the central part of the sample contains abundant zones in the form of needles attributed to ettringite (Figures 8(a) and 8(b)). The chemical compositions of the needles observed are given respectively in Figures 9 and 10 where the ettringitic nature of the needles observed is confirmed.

\subsection{SEM examination and EDS analysis: Case study 2}

\subsection{1 outside area}

The outer part of the pipe shows a porous concrete with the appearance of even cracks in Figure 11(a). Crystals of calcite are visible in the same Figure 11(a), developed in their usual forms. In contrast, calcite mixed with cement paste is observed in Figure 11(b). The formation of calcite crystals is favored by the high porosity of the conduit material which facilitates the penetration of atmospheric $\mathrm{CO}_{2}$.

\subsubsection{Inner area}

Figure 12 represents the SEM observation of the internal part in contact with the effluents of the pipe. Overall, the concrete in this area is significantly altered and has irregularities.

According to Figure 12, hydrated calcium aluminates (CAH) are identified in the form of dense crystals, next to the latter; it can be also distinguish needles likely corresponding to ettringite. The EDS analysis of the points of spectra 1 and 3 of Figure 12 are given in Figures 13 and 14, respectively, in which the chemical composition of the sub-cited products (ettringite and $\mathrm{CAH}$ ) are confirmed. On the other hand, we can 
also note the presence of a small quantity of $\mathrm{Si}$ which means that hydrated calcium silicates are also present in this internal part of the sample.

\subsubsection{Median zone}

Like the internal part in contact with the effluents, the same products are detected in the middle of the sample, namely ettringite needles and hydrated aluminates and calcium silicates in the form of crystals as shown in Figure 15. The porosity of the concrete is high even at the central part of the pipe.

\subsection{Density and porosity accessible to water}

The results of the AFREM cross-tests for the determination of the apparent density and the porosity accessible to water of the specimens are given in Table 1 . The tests were performed using the recommended AFREM procedure [19]. The value given represents the average of three samples.

From the results obtained, it is noted that the values of the porosity accessible to water of the concretes of service pipes (cases 1 and 2) are greater (twice as much) than the reference concrete (new pipe), this is an indicator of material damage knowing that open porosity is considered a first-rate parameter with regard to the durability of concretes.

On the other hand, the density values of the reference concrete are much higher. It may also be noted that the samples taken in the radial direction $(\mathrm{R})$ are more affected by this alteration with larger values than those of the samples (T) and (L), this can be explained by the permanent contact of the ends of the (R) sample with internal and external environments that represent sources of aggressive agents. On the other hand, this anisotropy is not observed for the sample of the reference concrete where the values are almost identical in all directions and this is valid for the two properties (density and porosity). 


\section{Conclusions}

The SEM and EDS analysis on the internal, external and middle faces of the thickness are performed and a report is produced in order to identify the phases present and detect the major pathologies on the micro scale.

Indeed, the degradations take different forms depending on the quality of the concrete, the nature of the network (unitary, rainwater or separative), the effluents, the soil and the support materials. Attacks and pathologies can be detected in areas in contact with soil or effluent. From this research, it could be concluded that:

- The surface of the external part is very often carbonated, with the formation of calcite crystals $\mathrm{CaCO}_{3}$ thus contributing to the decrease of the $\mathrm{pH}$ value of the concrete. Sometimes, the carbonation reaches even the central part of the sample.

- The internal face of the pipes is often degraded by the sulphates present in the effluents. The presence of sulphates with high concentrations reacts with the portlandite $\mathrm{Ca}(\mathrm{OH})_{2}$ of the cementitious matrix to form fibrous gypsum.

- External corrosion of the sewer has been noted within the network - this requires further analysis to identify the cause. There are potential problems with pyrite from the native sub soils, altered biovérien schist; there is also the possibility of pyrite contaminated backfills being used. In the area of Rennes crushed rock used for backfill, such as Horsfel or schist, may have pyrite contamination. It is recommended that in future soil sample and backfill are recovered for analysis.

- SEM observations confirmed the presence of ettringite in its characteristic form 
(needles). Its chemical composition is confirmed by microanalysis (EDS). This ettringite can be primary training or secondary training. The latter is an expansive product, which can cause cracks and damage to the structure.

- In sewage conditions, the degradation of concrete is mainly summarized by the action of a double attack, acid and sulphate. This double mechanism of acid and sulphate attacks can be written in a simplified way as follows:

- Acid attack: dissolution of hydrated lime with formation of gypsum

$$
\mathrm{Ca}(\mathrm{OH})_{2}+\mathrm{H}_{2} \mathrm{SO}_{4} \longrightarrow \mathrm{CaSO}_{4}+2 \mathrm{H}_{2} \mathrm{O}
$$

- Sulphate attack: reaction between cement aluminates $\left(\mathrm{C}_{3} \mathrm{~A}\right)$ and gypsum to form secondary ettringite.

$$
3 \mathrm{CaO} \cdot \mathrm{Al}_{2} \mathrm{O}_{3}+\mathrm{CaSO}_{4}+32 \mathrm{H}_{2} \mathrm{O} \longrightarrow 3 \mathrm{CaO} \cdot \mathrm{Al}_{2} \mathrm{O}_{3} \cdot 3 \mathrm{CaSO}_{4} \cdot 32 \mathrm{H}_{2} \mathrm{O}
$$

\section{Acknowledgements}

This work was done at the Laboratory of Civil Engineering, Mechanical Engineering (Materials) of the National Institute of Applied Sciences (INSA) of Rennes (France). This work is part of a research project between INSA and the City of Rennes. The authors would like to warmly reiterate all the staff of the center with these different laboratories as well as the Faculty of Sciences of the Rennes University.

Conflict of interest: On behalf of all authors, the corresponding author states that there is no conflict of interest.

\section{References}

[1] O’Connell, M., McNally, C., Richardson, M.G. Biochemical attack on concrete in wastewater applications: A state of the art review. Cement \& Concrete Composites 32 (2010) 479-485.

[2] Grandclerc, A., Guéguen-Minerbe, $\mathrm{M}$ and Chaussadent, T. Accelerated biodeterioration test of cementitious materials in sewer networks, RILEM 253- 
MCI Conference Microorganisms-Cementitious Materials Interactions, 25-27 June 2018, Toulouse.

[3] Olmsted, F-H., Hamlin, H. Converting portions of the Los Angeles outfall sewer into a septic tank. Eng News 1900; 44(19):317-8.

[4] Parker, C.D.,. Species of sulphur bacteria associated with the corrosion of concrete. Nature, 159, 439-40. (1947).

[5] Okabe, S., Odagiri, M., Ito, T., Satoh, H. Succession of sulfur-oxidizing bacteria in the microbial community on corroding concrete in sewer systems. Applied and Environmental Microbiology 73(3), 971-980. (2007).

[6] Zhang, L, De Schryver, P., De Gusseme, B., De Muynck, W., Boon, N., Verstraete, W. Chemical and biological technologies for hydrogen sulfide emission control in sewer systems. Water research 42 (2008), 1-12.

[7] Brongers, M., Koch, G., Thompson, N. Corrosion costs and preventive strategies in the United States, Report FHWA-RD-01-156, Federal Highway Administration, Washington, DC. (2001).

[8] Herisson, J., Eric, D., Van Hullebusch, Gueguen Minerbe, M., Taquet, P., Eychenne-Baron, C., Chaussadent, T. Better durability of calcium aluminate cement regarding biocorrosion in sewer networks, 1st International Conference on the Chemistry of Construction Materials, Germany. 5 p, (2013).

[9] Hvitved-Jacobsen, T., Vollertsen, J., Matos, J.S. The sewer as a bioreactor - a dry weather approach. Water Science and Technology. 45(3), 11-24. (2002).

[10] Sydney, R., Esfandi, E., Surapaneni, S. Control concrete sewer corrosion via the crown spray process. Water Environ. Research. 68 (3), 338-347. (1996).

[11] Tazaki, K., Mori, T., Nonaka, T. Microbial jarosite and gypsum from corrosion of Portland cement concrete. Canadian Mineralogist 30, 431 - 444. (1992).

[12] De Graef, B., Cnudde, V., Dick, J., De Belie, N., Jacobs, P., Verstraete, W. A sensitivity study for the visualization of bacterial weathering of concrete and stone with computerized X-ray microtomography. Science of the Total Environment 341, 173 - 183. (2005). 
[13] Lea, F-M., \& C. H. Desch. The chemistry of cement and concrete. Edward Arnold \& Co. London, UK. (1935).

[14] Parker, C.D. The Corrosion of Concrete. The Function of ThiobacillusConcretivorus (Nov-Spec) in the Corrosion of Concrete Exposed to Atmospheres Containing Hydrogen Sulphide. Australian Journal of Experimental Biology and Medical Science 23(2), 91-98. (1945).

[15] Davis, J.L., Nica, D., Shields, K., Roberts, D.J. Analysis of concrete from corroded sewer pipe. International Biodeterioration and Biodegradation 42, 7584. (1998).

[16] Mori, T., Nonaka, T., Tazaki, K., Koga, M., Hikosaka, Y., Noda, S. Interactions of nutrients, moisture and $\mathrm{pH}$ on microbial corrosion of concrete sewer pipes. Water Research. 26, 29-37. (1992).

[17] Oualit, M., Jauberthie, R., Melinge, Y., Abadlia, M-T. Performance and analysis of concrete in sewer environment: Anisotropy of damage. Applied Mechanics and Materials, 146 (2012) pp 147-159.

[18] Oualit, M., Jauberthie, R., Rendell, F., Melinge, Y., Abadlia, M-T. External corrosion to concrete sewers: a case study. Urban Water Journal, 9(6), 429-434. (2012).

[19] Ollivier, J-P. Les résultats des essais croisés AFREM pour la détermination de la masse volumique apparente et de la porosité accessible à l'eau des bétons [The results of the AFREM cross-tests for the determination of the apparent density and the water-accessible porosity of concretes], Compte rendu des journées techniques AFPC-AFREM, Durabilité des bétons, Méthodes recommandées pour la mesure des grandeurs associées à la durabilité, pp 121-124, Toulouse, France. (1997). 
Figure 1. Process and corrosion mechanism that occurs in sewers concrete structures.
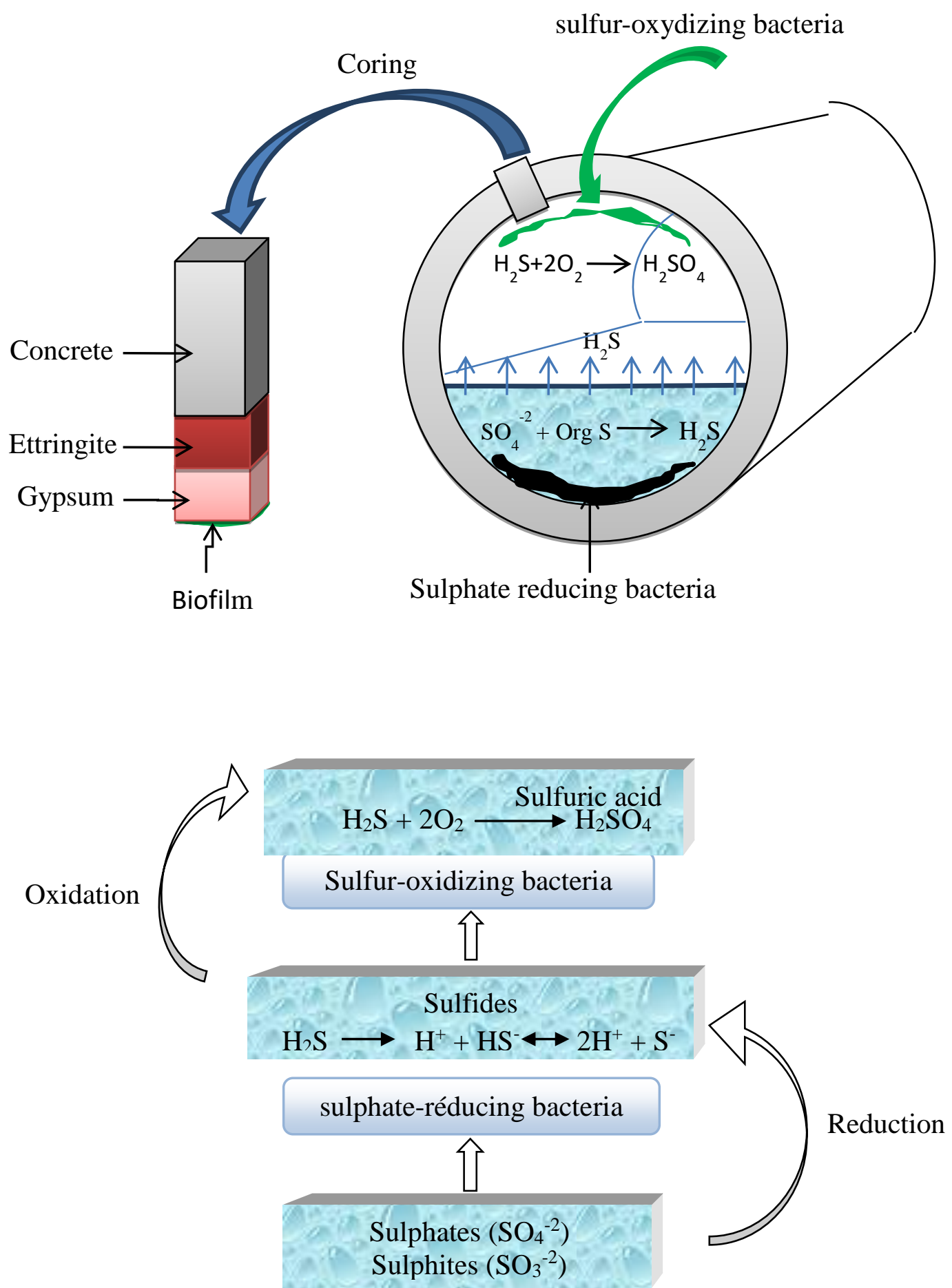
Figure 2. SEM visualizations of a concrete fragment located near the outer face.
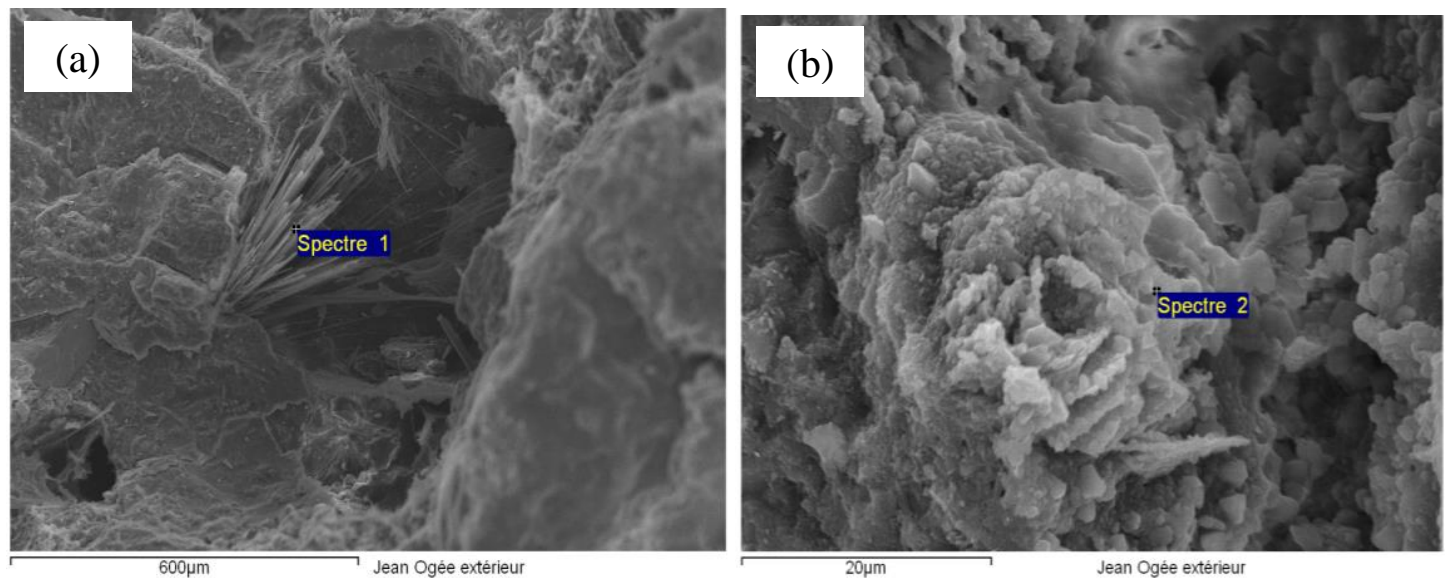

Figure 3. EDS analysis performed at spectrum point 1 of Figure 2(a) with details of the compounds.

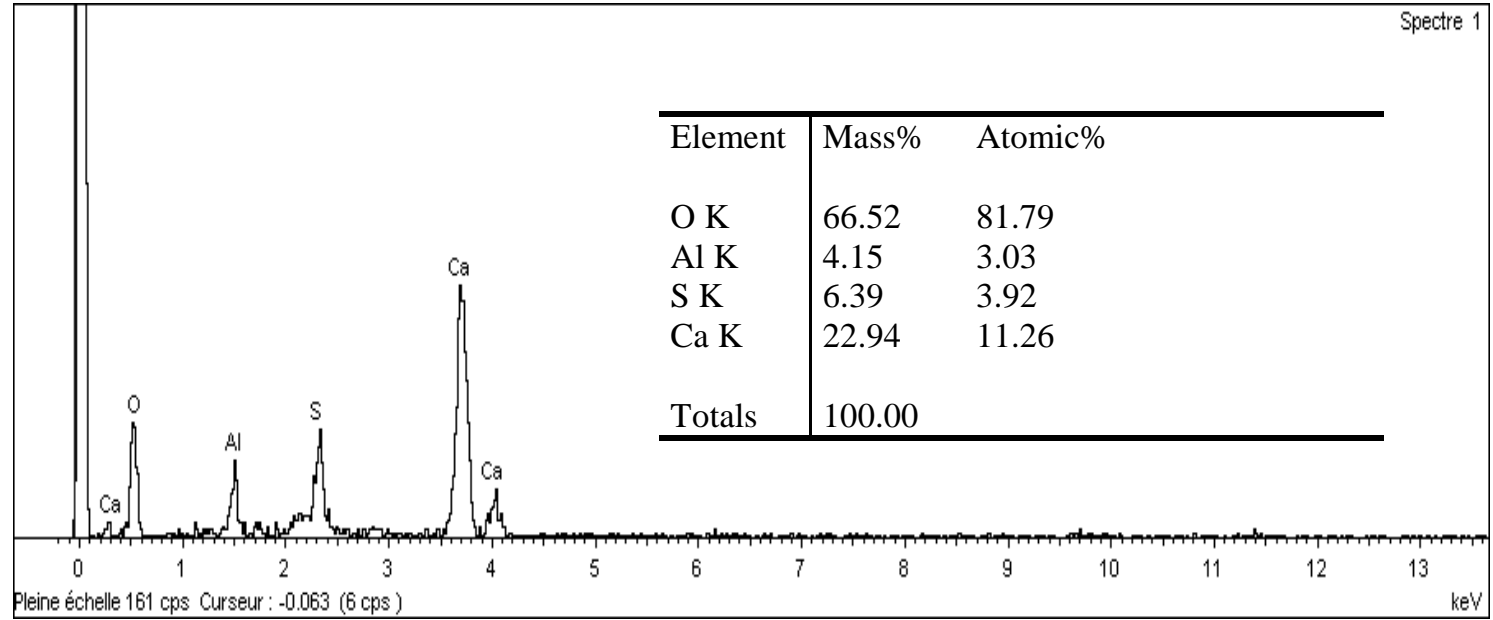

Figure 4. EDS analysis performed at spectrum point 2 of Figure 2(b) with details of the compounds.

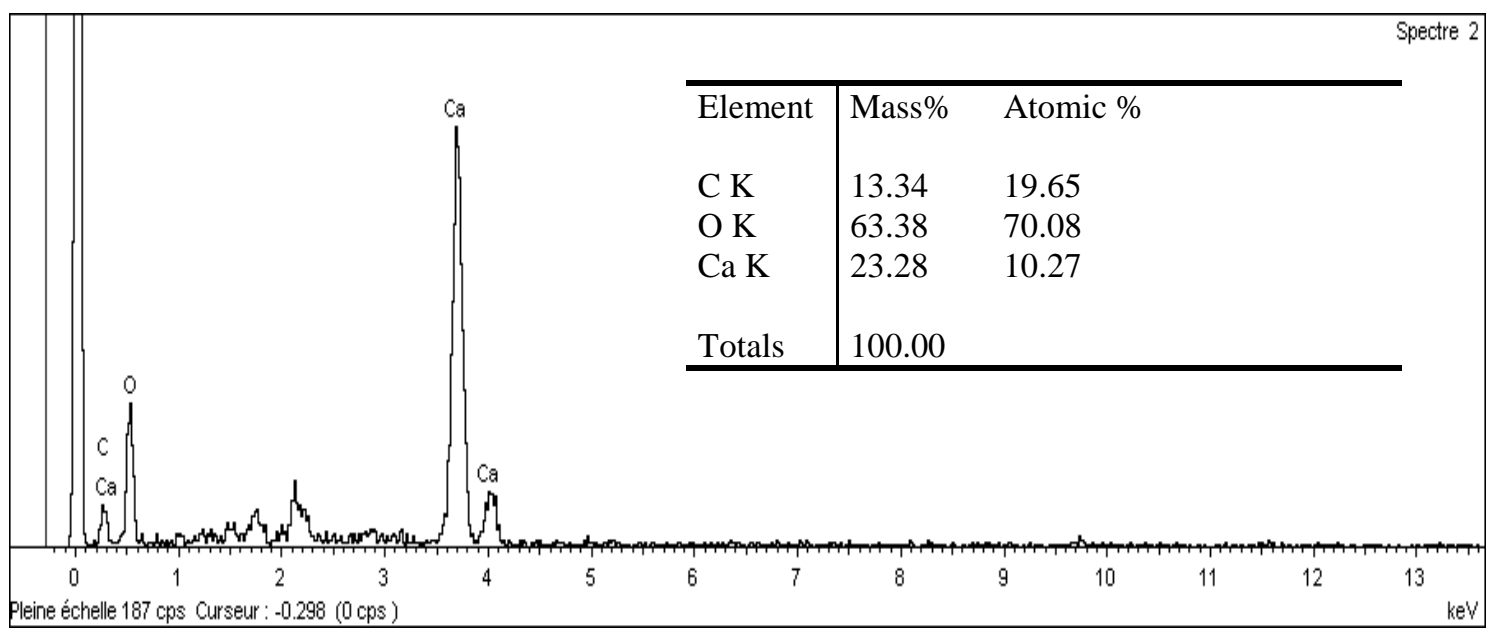


Figure 5. SEM visualizations of a concrete fragment located near the inner face.
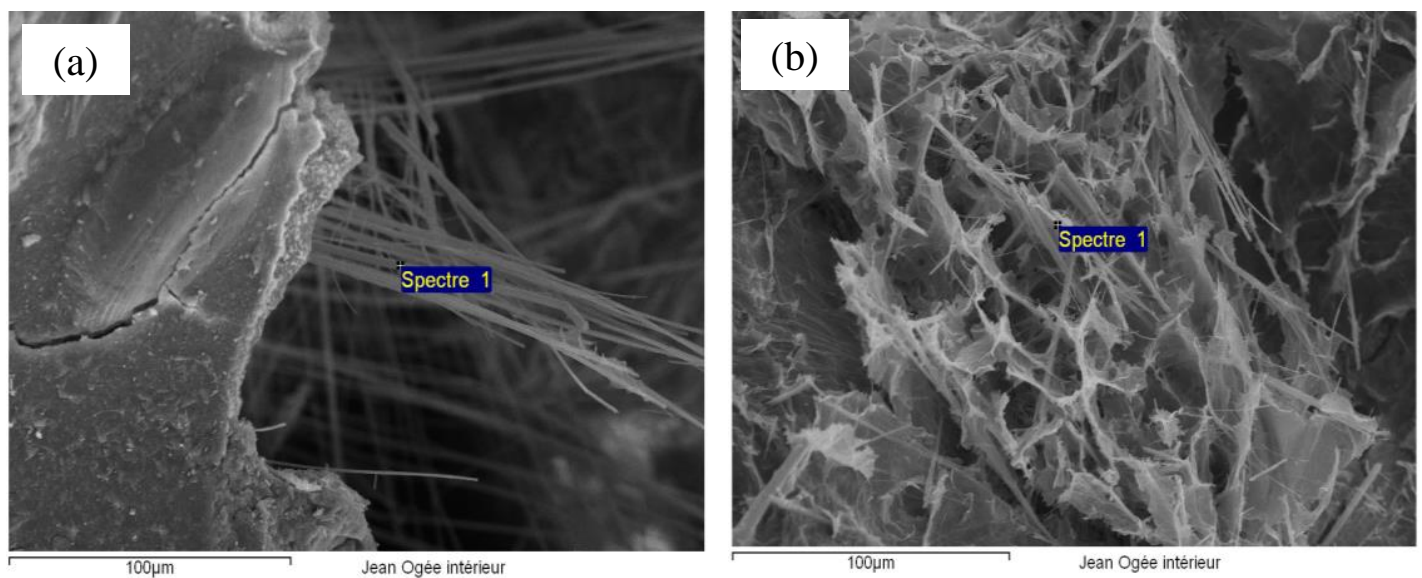

Figure 6. EDS analysis performed at spectrum point 1 of Figure 5(a) with details of the compounds.

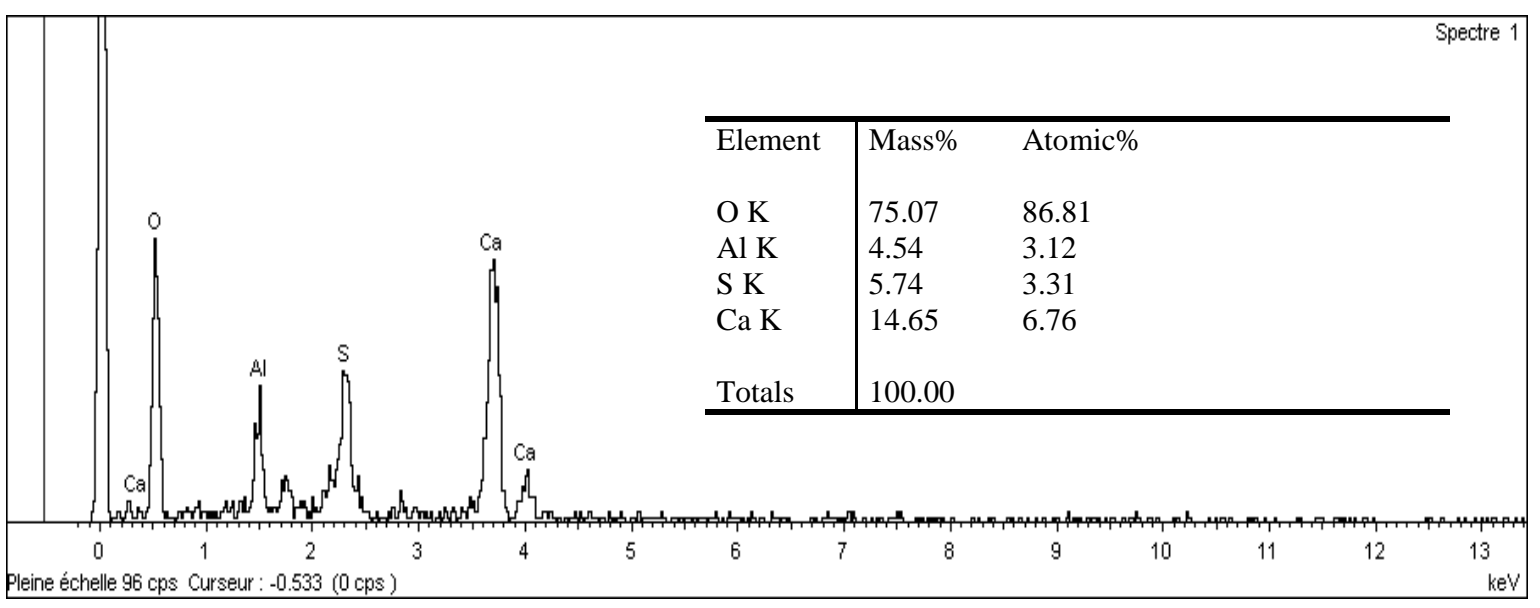

Figure 7. EDS analysis performed at spectrum point 1 of Figure 5(b) with details of the compounds.

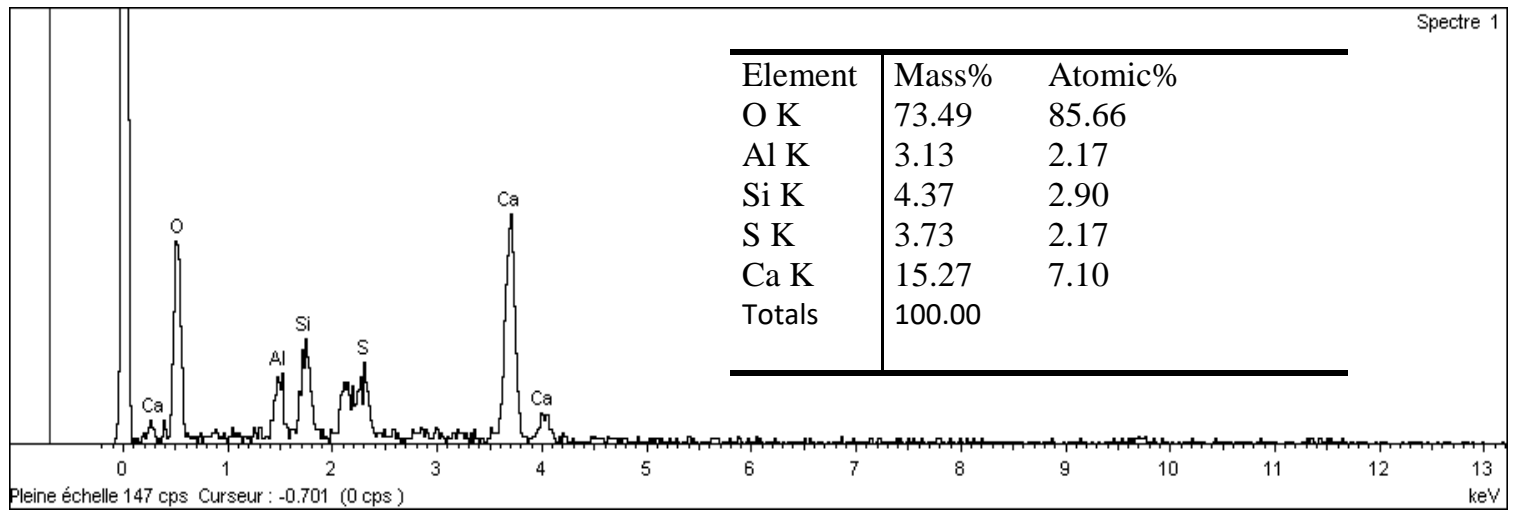


Figure 8. SEM visualization of a fragment of concrete located at the central zone.
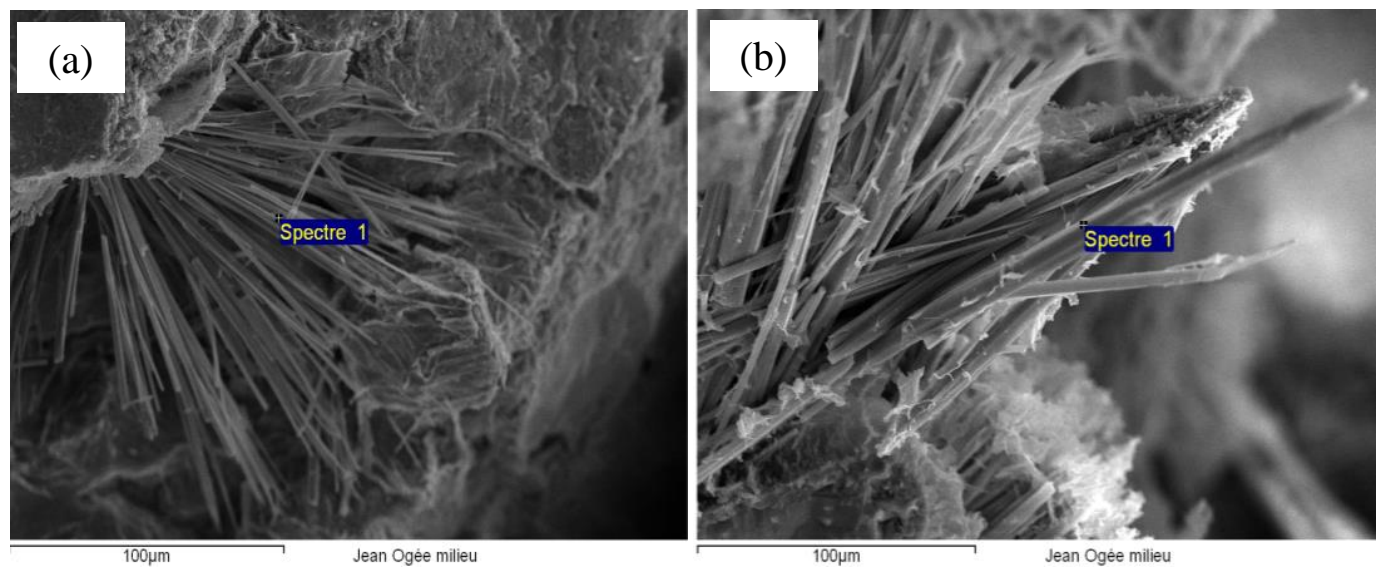

Figure 9. EDS analysis performed at spectrum point 1 of Figure 8(a) with details of the compounds

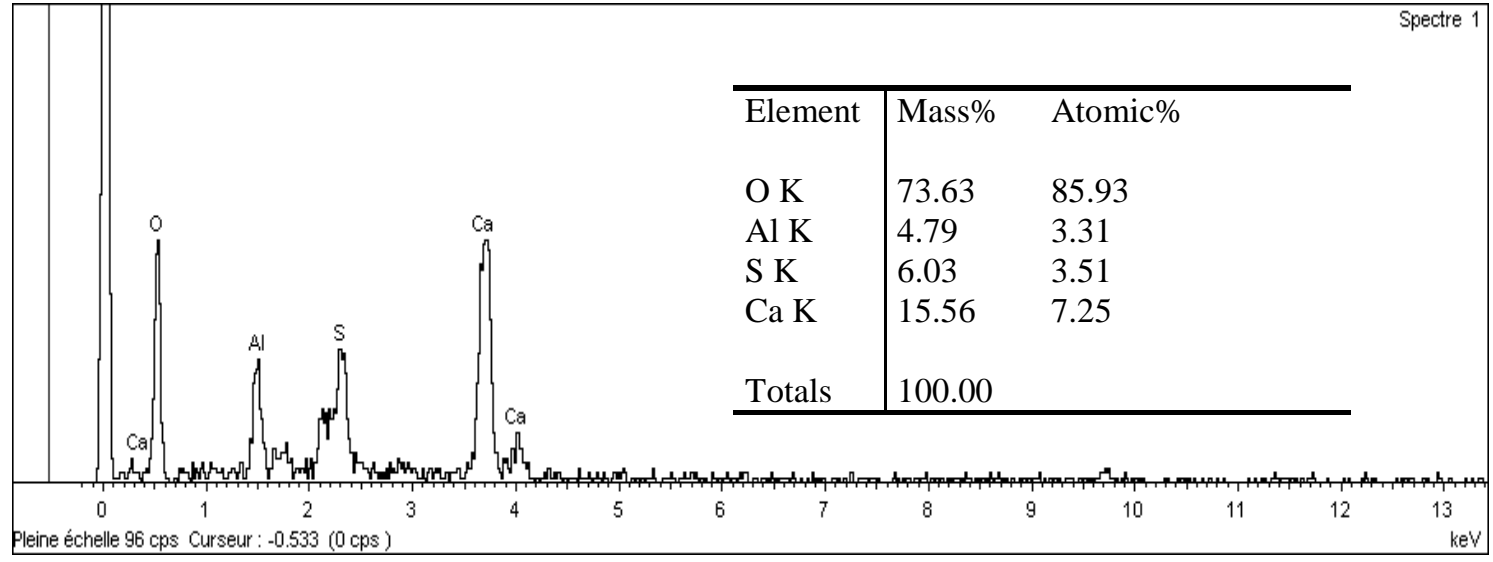

Figure 10. EDS analysis performed at spectrum point 1 of Figure 8(b) with details of the compounds

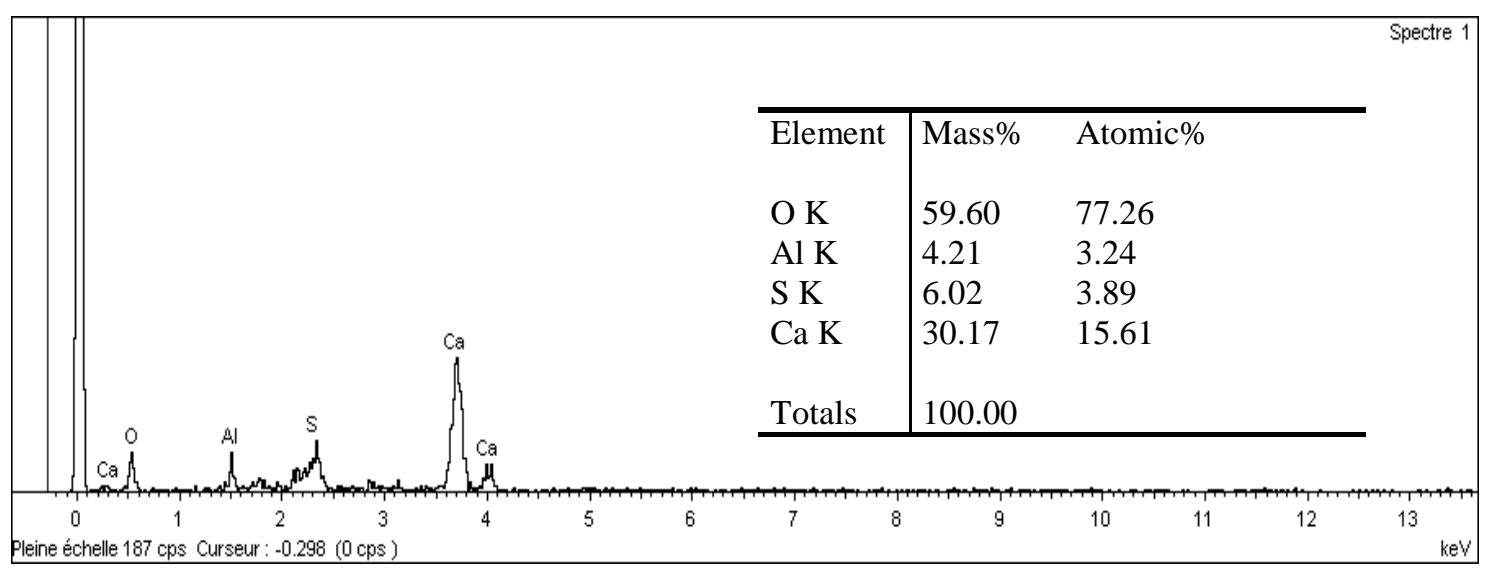


Figure 11. SEM visualizations of a concrete fragment located near the outer face.
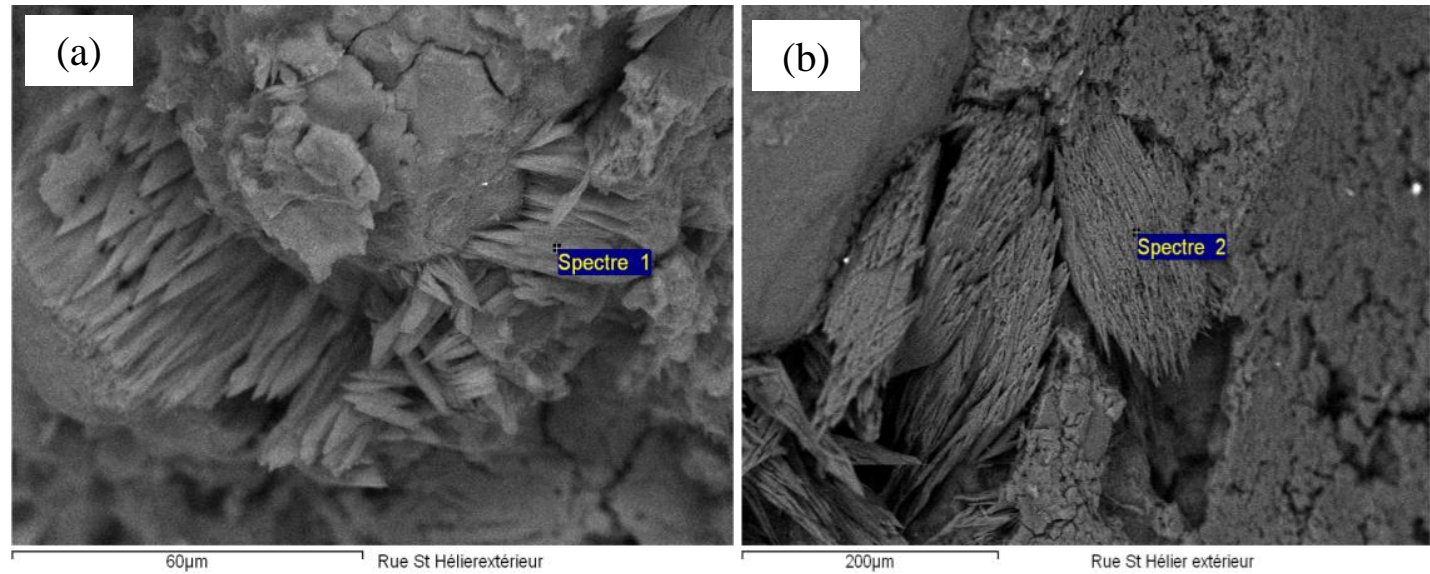

Figure 12. SEM visualizations of a concrete fragment located near the inner face.
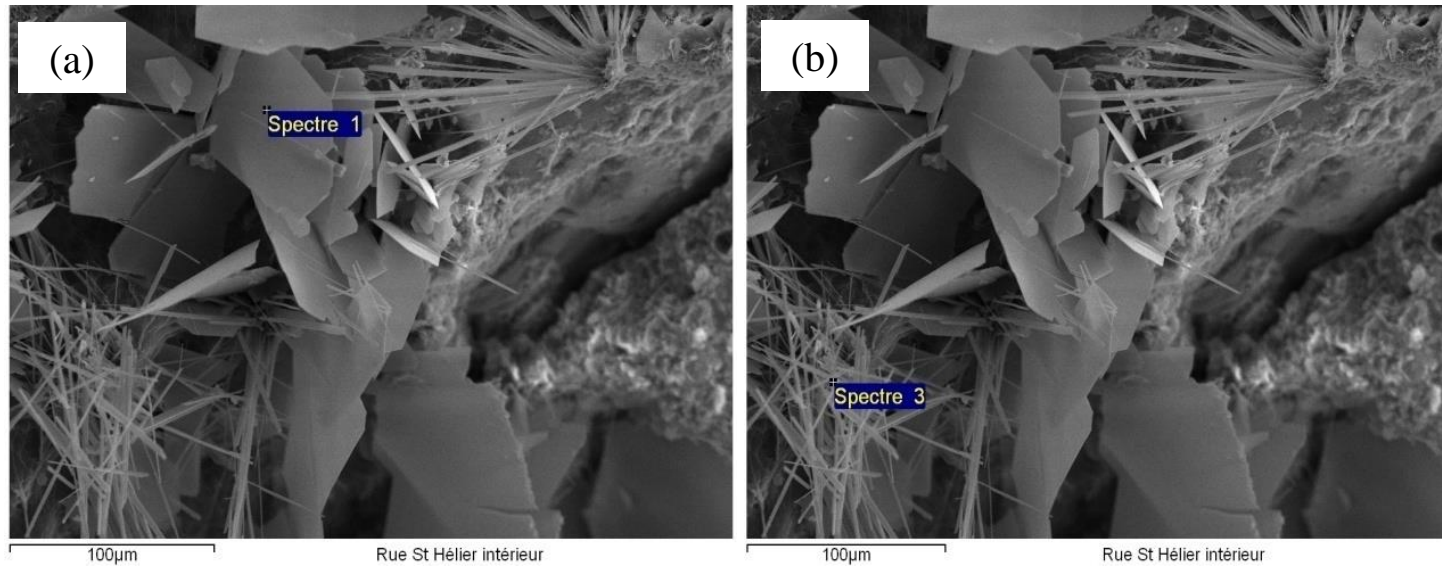

Figure 13. EDS analysis performed at spectrum point 1 of Figure 12(a) with details of the compounds.

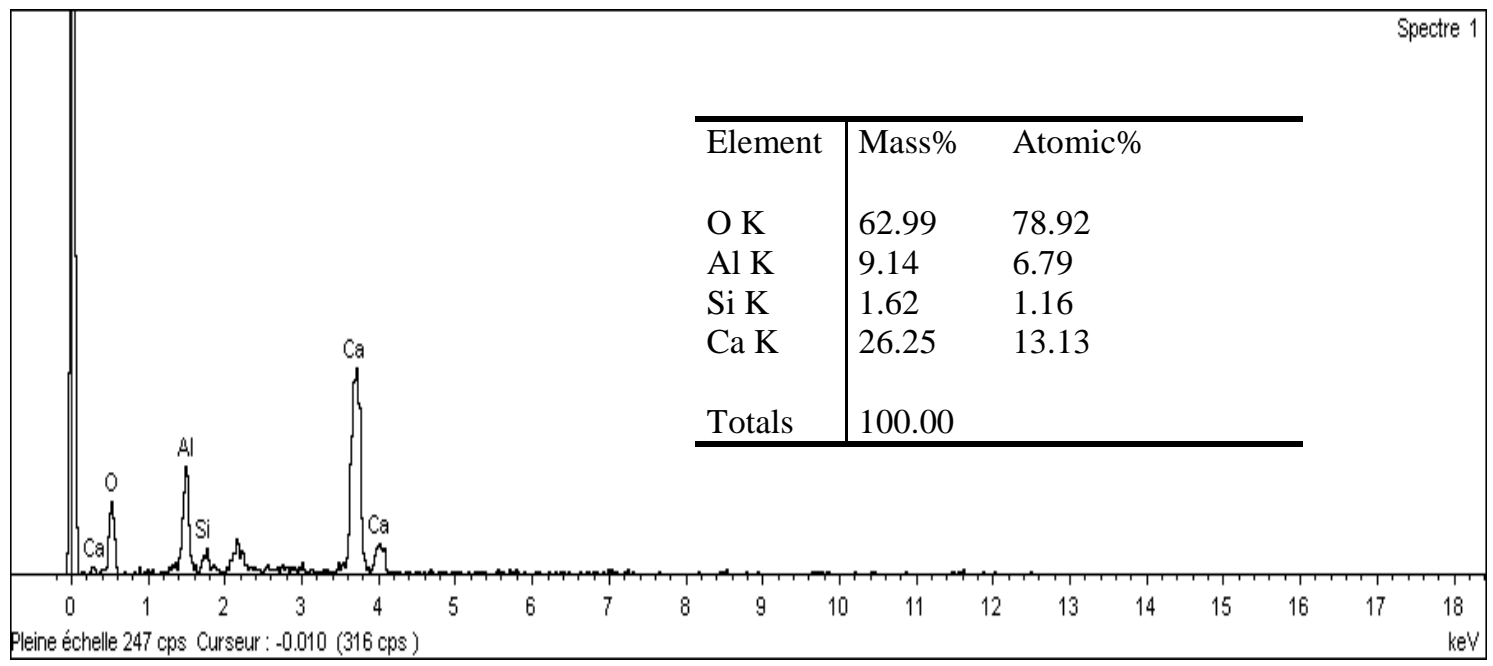


Figure 14. EDS analysis performed at spectrum point 3 of Figure 12(b) with details of the compounds.

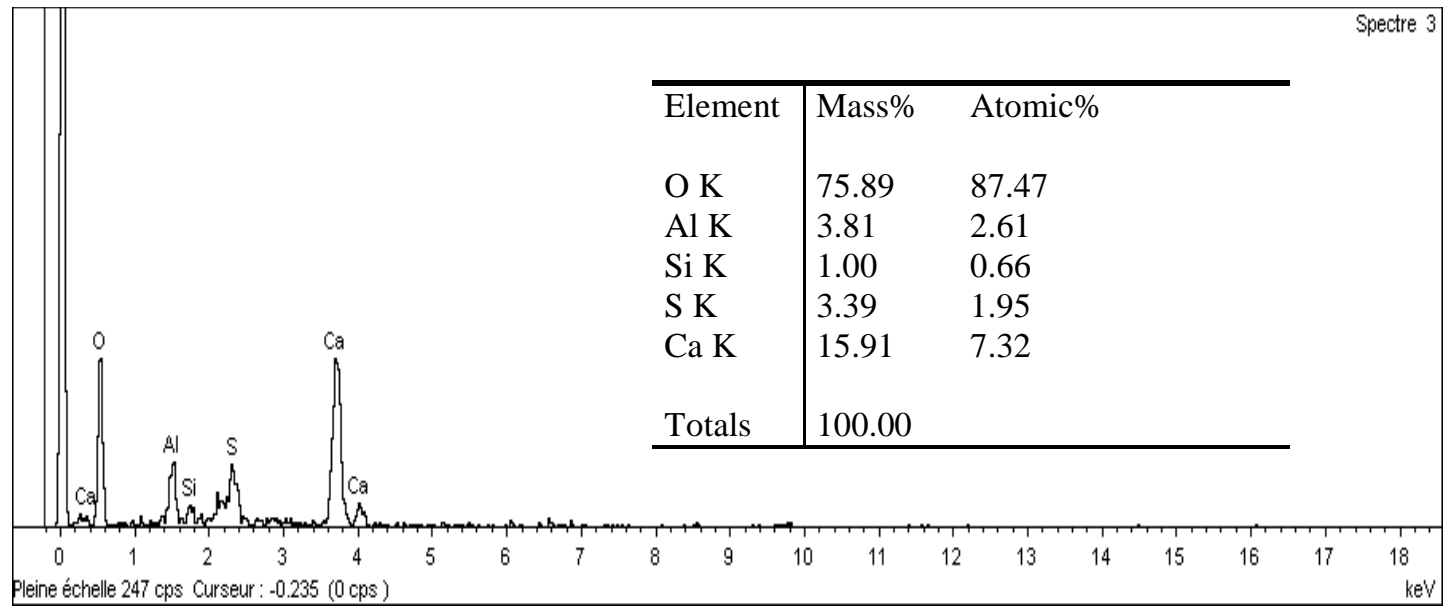

Figure 15. SEM visualization of a fragment of concrete located at the central zone.
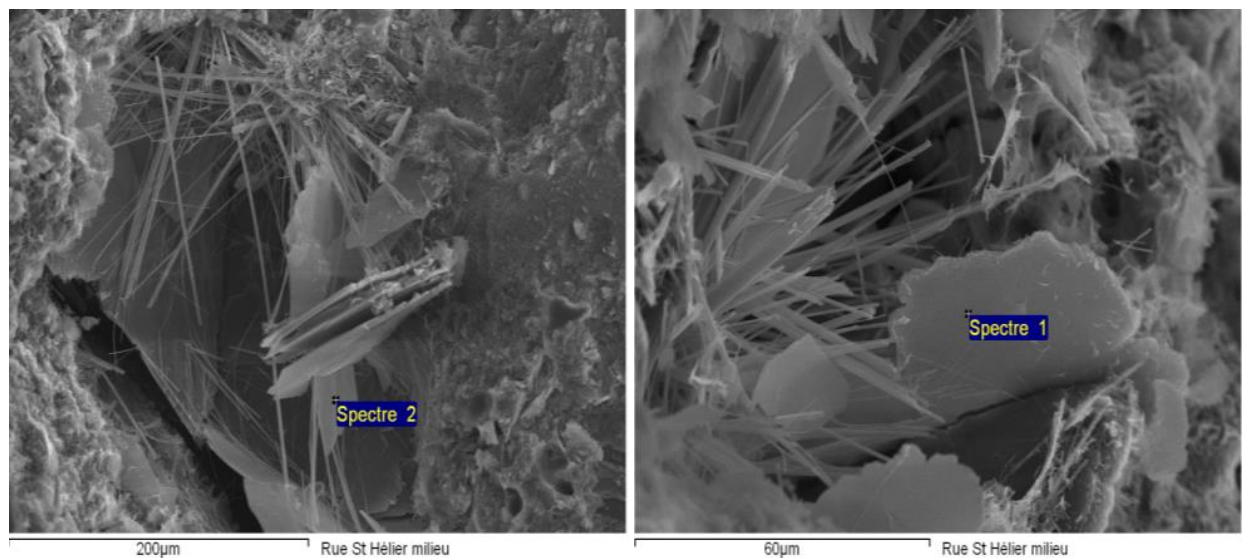
Table 1. Results of cross-tests of apparent density and porosity accessible to water.

\begin{tabular}{|c|c|c|c|c|c|c|}
\hline & Sample & $\mathrm{M}_{\text {eau }}(\mathrm{g})$ & $\mathrm{M}_{\text {air }}(\mathrm{g})$ & $\mathrm{M}_{\text {sec }}(\mathrm{g})$ & $\rho_{\mathrm{d}}\left(\mathrm{g} / \mathrm{cm}^{3}\right)$ & $\varepsilon(\%)$ \\
\hline \multirow{3}{*}{$\begin{array}{c}\text { Ref } \\
\text { concrete }\end{array}$} & R sample & 59,680 & 100,347 & 97,195 & $\mathbf{2 , 3 9 0}$ & $\mathbf{7 , 7 5 0}$ \\
\cline { 2 - 7 } & T sample & 46,458 & 78,072 & 75,740 & $\mathbf{2 , 3 9 5}$ & $\mathbf{7 , 3 7 6}$ \\
\cline { 2 - 7 } & L sample & 48,066 & 81,152 & 78,396 & $\mathbf{2 , 3 6 9}$ & $\mathbf{8 , 3 2 9}$ \\
\hline \multirow{3}{*}{$\begin{array}{c}\text { Case } \\
\text { study } 1\end{array}$} & R sample & 44,293 & 77,395 & 71,570 & $\mathbf{2 , 1 6 2}$ & $\mathbf{1 7 , 5 9 7}$ \\
\cline { 2 - 7 } & T sample & 36,647 & 63,610 & 59,440 & $\mathbf{2 , 2 0 4}$ & $\mathbf{1 5 , 4 6 5}$ \\
\cline { 2 - 7 } & L sample & 30,526 & 51,909 & 48,694 & $\mathbf{2 , 2 7 7}$ & $\mathbf{1 5 , 0 3 5}$ \\
\hline \multirow{3}{*}{$\begin{array}{c}\text { Case } \\
\text { study } 2\end{array}$} & $\mathrm{R}_{\text {int }}$ sample & 29,826 & 52,190 & 48,272 & $\mathbf{2 , 1 5 8}$ & $\mathbf{1 7 , 5 1 9}$ \\
\cline { 2 - 7 } & T sample & 34,901 & 61,048 & 56,613 & $\mathbf{2 , 1 6 1}$ & $\mathbf{1 6 , 9 3 2}$ \\
\cline { 2 - 7 } & L sample & 36,644 & 64,055 & 60,059 & $\mathbf{2 , 1 9 1}$ & $\mathbf{1 4 , 5 7 8}$ \\
\hline
\end{tabular}

$\mathrm{M}_{\text {eau: }}$ Mass of the sample weighed under water, (hydrostatic weighing), (g).

$\mathrm{M}_{\text {air: }}$ : Mass of the saturated sample weighed in air, $(\mathrm{g})$.

$\mathrm{M}_{\mathrm{sec}}$ : Mass of the dry sample, $(\mathrm{g})$.

$\rho_{\mathrm{d}}$ : Bulk density, $\left(\mathrm{g} / \mathrm{cm}^{3}\right)$.

$\varepsilon$ : Porosity accessible to water, $(\%)$. 